\title{
Management Practices of School Heads, Organizational Behavior, and Performance of Teachers in Distance Learning Environment
}

\author{
Starsky M. Buitizon \\ Laguna State Polytechnic University, Philippines
}

\begin{abstract}
This study determined the management practices of school heads, organizational behavior, and performance of teachers in the distance learning environment. Fifty-five (55) public school principals and one thousand five hundred seven (1507) teachers were the respondents of the study. The researcher utilized the descriptive-correlational examination plan, which utilized the adopted and modified questionnaires to assess and measure the variables under study. The statistical tools used to analyze the data gathered were: Frequency and Percentage, Mean, Standard Deviation, and Multiple Linear Regression Analysis. Findings revealed that the management practices, organizational behavior, and performance of teachers were relevant to the distance learning environment. The findings were used to determine the strategic plan model to be proposed by the DepEd and school officials. Since the school heads' management practices are assessed to a high extent, it may be sustained by introducing innovations in their respective stations, which will focus on how the instructional programs may be carried out to achieve the vision, mission, and goals of the DepEd. This may be done by involving the teachers in the instructional decisions to be made as well as in crafting the different plans to be implemented in the school context. The teachers may be exposed to seminars and capability building to further enhance their teaching pedagogy as well as their skills in the different aspects of the instructional program in the context of the new normal in the educational system.
\end{abstract}

Keywords: Management Practices, Organizational Behavior, the Performance of Teachers

\section{INTRODUCTION}

This is an open access article under the CC-BY-NC license.

Change is inevitable. Nations around the world embrace and promote a wide range of educational reforms to meet the demands of life and to prepare our school heads, teachers, and learners in dealing with the challenges, particularly in facing this pandemic COVID 19.

$\mathrm{K}$ to 12 education system is a relevant example that facilitates changes and serves as a standard for basic education globally. This allows fundamental training schools experienced rebuilding in the educational plan, yet in addition in monetary and HR (Sarvi et al.,2015).

Today, educational leaders have a great role in the school setting. Principals can work with or prevent the interaction of progress through their activities by the manner in which they lead, oversee, lead school-based preparing and expert advancement programs, impart and activate assets with the end goal of the instructing learning measure. Indeed, they are the ones engaged in the holistic development of the educational institution.

For many years, the chief used to perform the board's routine undertakings like arranging, sorting out, checking, and assessing. These undertakings are proven in providing orders, managing the school financial plan, orchestrating homerooms schedules, checking participation and nonattendance of instructors and understudies. Those undertakings are thought of as areas yet seen as significant. Be that as it may, numerous administrators are assuming the normal, worn-out parts with a little spotlight on instructors' presentation, which could further develop understudies learning. This image of the key's jobs ruled their schools for an extensive stretch of time, yet presently, in the new typical, it is an ideal opportunity to move and find a series of ways to change this picture.

With the appearance of significant changes in the system, particularly in education also, the changing possibilities for the alumni required for the new economy, this perspective on the jobs of the administrators has changed. 
Therefore, the difficulties are schools confronted with not just a bounty of information and mechanical developments in all fields yet additionally with many difficulties to a compelling learning measure.

The section of Republic Act 9155 of every 2001 gave the Branch of Schooling (DepEd) the legitimate command to revamp administration in essential training. With such mandate, school-based administration (SBM) turned into the system for rolling out institutional improvements to further develop primary school students" learning (DepEd, 2006).

Schools need pioneers with the vision to further develop the learning climate of the educational system as a feature of the useful school-based administration (SBM). Moreover, as cited by Busu and Draga (2017) in their study, SBM includes a set system school with respect to students, educator improvement, and the assignment of monetary and material assets.

Smolag \& Slusarczyk (2017) stressed that a powerful administration framework affects the inspiration and responsibility of educators to deliver fruitful understudies by working with school executives that are both suitable to the specific situation and to the necessities of the school, and to the turn of events and execution of plans to work on the school, to the foundation of reasonable and compelling assessment frameworks for instructors, to structure study halls and schools as indicated by the requirements, to the structure of an organization with the local area, and to guarantee that there is staff to help school elements of different offices.

The foregoing facts and findings from literature and studies have prompted the researcher to conduct a deeper study on the school heads' change management practices as they impact the quality of instruction and consequently come up with a strategic plan model for school heads.

\section{LITERATURE REVIEW}

\section{Management practices}

Management practices have a solid relationship with a guarantee to change. The responsibility of association individuals is basic for any change work to succeed, and the ability to induce obligation to change is a significant quality of association pioneers (Ashkenas et al., 2013).

As heads of schools, administrators are normally the change specialists in the association (Hechanova and Cementina-Olpoc 2013; Parco-Tropicales and de Guzman 2014). Studies have proposed that these pioneers should start change, keep an encouraging group of people, and practice moral and proactive authority in the midst of progress.

One of the least demanding approaches to comprehend the executives rehearses in training is to initially consider the board rehearses as an idea. By and large, the executive's rehearses are the way toward administering any significant change in a framework to guarantee the cycle happens as effectively and rapidly as could really be expected. This can incorporate overseeing HR to guarantee individuals see how the change is happening, building up how the change will happen and making measures for assessing the change, and at last, trying these ideas. As a term, it can regularly allude to any cycle of progress. The executives rehearse in instruction basically alludes to this cycle as it applies to any arrangement of schooling.

In state-funded training, the board rehearses, for the most part, allude to executing and assessing changing arrangements set up by governments or other administrative instructive organizations. The No Youngster Abandoned (NCLB) program set up in the US in the early long periods of the 21st century is one cycle in which this sort of work can be seen. Legitimate administration rehearses important to guarantee that educators and staff had the option to appropriately comprehend the progressions made by NCLB and execute those changes. By using the board rehearses in instruction, this cycle had 
the option to happen reasonably without a hitch, and different techniques for the examination of these progressions were established to later pass judgment on the benefits of the changes.

The executives rehearse in training can likewise be used for advanced education and frequently manage changes in innovation or instructing strategies. For instance, if a school or college were to zero in more vigorously on "E-learning" and wipe out the vast majority of its homerooms, then, at that point, this interaction would be appropriately overseen. This would not just incorporate the real execution of such a change, yet guarantee that educators saw how to function inside the changing framework and assist understudies with learning the help of new innovation. Comparative administration practices would almost certainly be important if a college chose to urge educators to turn out to be more aloof in training and serve principally as facilitators instead of a customary technique that had been used at the school. ( https://www.wisegeek.com/what-is-changemanagement-in-education.htm).

Elements of change. There are important change concepts to explore in relation to mergers. According to Burke (2014), the large majority of changes are evolutionary in nature. Evolutionary change is "Typically an attempt to improve aspects of the organization that will lead to higher performance. The fundamental nature, or deep structure of the organization, its culture, for example, remains undisturbed" (Burke, 2014, p. 98).

Levels of change. Change can occur at various levels of an organization. Burke (2014) described three levels of change: individual, group, and system. "Organizational change at the individual level is influenced by (a) recruitment, selection, and replacement; (b) the extent to which the organization instills the principles of a learning organization; and (c) coaching and counseling". Individual change is predicated on the need to move the organization forward, even if this results in a workforce reduction. British Airways' decision to reduce the workforce by approximately 20,000 workers validated this phenomenon. This large reduction in workforce assisted the organization in moving forward in a more profitable direction (Burke, 2014). This type of change is also reflective in the appointment of a new CEO, most often from outside the organization. Training, coaching, and counseling are all aimed at the individual level (Burke, 2014).

A second level of change is group change. Burke (2014) reminded readers that "Organization change efforts typically rely heavily on the use of work groups" The group as a whole has to make changes in their procedures and often benefit from team building activities. He suggested four purposes for team building. These include setting priorities for the group, examining communication and decisionmaking roles of the group members, assessing interpersonal relationships, and determining the various roles for the team members.

In discussing the third level of change, Burke (2014) claimed that "The larger-system level is so complex it is useful to think strategically about different orders of change". A first-order change is a result of an intervention in a subsystem of the organization. A second-order change occurs in response to the first-order change. A third-order change "eventually influences some organizational process or outcome that is affected by multiple factors. Third-order change, therefore, means the involvement of multiple factors in some causal sequence toward an ultimate goal."

Individuals' responses to change may help or hinder organizational change and must be recognized. Burke (2014) suggested that stages of change are similar to the stages that individuals go through after a diagnosis of a terminal illness. These are (a) shock and denial; (b) anger; (c) bargaining; (d) depression; and (e) acceptance (. As organizations change, individuals will move from one stage to another or remain fixed in one stage. He argued that all change is a loss experience even when change is accepted and desired. 
As uncovered in Streams and Sutherland's (2014) concentrate on instructive administration, directors viably work with change by building up significant connections, acquiring assets, and giving proficient advancement freedoms to instructors to execute the change.

Magsaysay and Hechanova (2017) likewise investigated factors that add to the effective administration of progress. Their investigation of the viability of the board rehearses yielded ten administration rehearses measures. The first is arranging the methodology and cycle of progress. Another factor is imparting change-ensuring that individuals comprehend the justification of the change and what changes will be executed. Preparing additionally surfaced as a significant component in administration practices to guarantee that individuals have the capacities to execute the change. Arrangement and status were additionally seen as significant in viably overseeing change. This involves guaranteeing that representatives are prepared and sure about their capacity to carry out the change. Having a hierarchical culture steady of progress additionally guarantees a good outcome. Workers likewise anticipate that leaders should be noticeably and substantially supporting the change. Worker jobs and obligations and expectations during the change should be clear and checked. Besides, organizations must tackle advancements that empower individuals to work better during the change. Ultimately, the association's design and work process should uphold the change drive.

Guerrero, Teng-Calleja, and Hechanova (2018) highlighted that understood change initiative hypothesis (ICLT) features the significance of deciding coinciding between the ideal and genuine change authority patterns of representatives in fruitful administration rehearses. This examination used ICLT in investigating compelling change initiatives and the executives in optional schools and inspected how these impact educators' obligation to change. Information was assembled from 707 optional teachers from both private and public secondary schools in the Philippines. Discoveries showed that (1) educators appear to have a more comprehensive and integrative perspective on change initiative outlines than representatives of business associations, (2) instructors' change administration patterns altogether predicts apparent viability of the executives' practices, and educators' full of feeling an obligation to change, and (3) saw adequacy of the board rehearses fundamentally intercedes the impact of progress authority diagrams on educators' emotional obligation to change. This examination extended the relevance of ICLT in essential training settings and adds to the comprehension of the successful change initiative and the executives rehearses in schools.

Instructive issues emerge on the grounds that the school with the school head giving administration needs to start and advance instructive change in response to social changes in a broad sense, an increasing population, the growing impact of technology, and the increasing concern for disadvantaged or for depressed areas, and others.

Former DepEd Secretary Leslie A . Lapus commented that the achievement of school directors relies upon our uplifting outlook towards change. They should be the impetuses who won't just acknowledge changes and changes yet additionally lead and oversee changes.

Working with a synergistic climate, change-situated, where educators foster administration abilities and capabilities by seeking after shared objectives and keeping a majority rule and collegial work environment is another imperative for the execution of the effective initiative.

Working with a synergistic climate, change-situated, where educators foster administration abilities and capabilities by seeking after shared objectives and keeping a majority rule and collegial work environment is another imperative for the execution of the effective initiative.

The leader is the one who envisions the growth of the organization, and he is the one who solves problems. (Busu and Draga,2017) 
Legisma (2014) declared that school administrators management of change includes leadership, communication, and participation; teachers' social relations include (1) family aspect as relationship and support and (2) peer relations such as teachers personnel; and teachers' demographic profile was limited to their age, civil status, and educational attainment.

In terms of management of change of school administrators, leadership, communication, and participation, all were rated "Very Satisfactory" as sustained by computed r-values of $0.006,-0.023$ and 0.002 , t-stat of $0.057,-0.232$, and 0.018 , and $p$ values of $0.995,0.817$ and 0.985 which was interpreted as "Not Significant" to the performance of the teachers.

In terms of social relations of teachers, which include family aspect as to the relationship and moral support, the two were rated "Very satisfactory " as sustained by computed r-values of -0.129 and 0.225 , t- stat of -1.295 and 2.295 , and p-values of 0.198 and 0.024 which revealed the relationship to be "Not Significant " and moral support as "Significant"; and peer relations as teacher and personnel, the two were rated " Satisfactory " and "Very Satisfactory " as sustained by the computed r-values of 0.112 and $-0,091$, t-stat of 1.119 and -0.913 and p-values of 0.266 and 0.364 which revealed to be " Not Significant " to the performance of the teachers.

Honrejas (2016), in his article in The Modern Teacher, stated that the school administrator's objectives might vary with the roles he plays in managing school in an era of change. The principal makes changes according to his perception of the need and asks the appropriate sector to implement them.

Accordingly, viable schools have pioneers who keep up with and support a scholastic accentuation that spotlights guidance. It is fundamental that administrators are noticeable in study halls. Grizzard's (2017) study demonstrated that main perceivability increments with suitable preparation. For sure, the investigation of Wakeley (2017) additionally exposes the ramifications for heads to become perceptive of how qualities can add to their adequacy as heads of progress

The following components highlight management practices, which include Designing Visions, Curriculum, and Instructions, Supervising Teachers, Monitoring Students Progress, and Protecting Instructional Climate with 10 indicators for each component.

\section{RESEARCH METHOD}

This research made utilized the descriptive-correlational technique to determine the management practices of school heads as well as the performance of teachers, which served as the basis in the formulation of the strategic plan model. The school heads and the teachers of the identified divisions were the respondents of the study.

\section{FINDINGS AND DISCUSSION}

Table 1. Distribution of the respondents in terms of sex

\begin{tabular}{ccccc}
\hline \multirow{2}{*}{ Sex } & \multicolumn{2}{c}{ School Head } & \multicolumn{3}{c}{ Teachers } \\
\cline { 2 - 5 } & $\mathrm{f}$ & $\%$ & $\mathrm{f}$ & $\%$ \\
\hline Male & 11 & 20.00 & 241 & 15.99 \\
Female & 44 & 80.00 & 1266 & 84.01 \\
\hline Total & 55 & 100.00 & 1507 & 100.00 \\
\hline
\end{tabular}

As shown in the table, forty four (44) or $80 \%$ of the school head respondents were females, and eleven (11) or $20 \%$ were males. In terms of the teacher-respondents, 1266 out of 1507 or $84.01 \%$ were females, and two hundred forty-one (241) or 15.99 were males. This means that majority of the respondents who took part in the study were all females. 
Table 2. Distribution of the respondents in terms of age

\begin{tabular}{ccccc}
\hline \multirow{2}{*}{ Age Group } & \multicolumn{2}{c}{ School Head } & \multicolumn{3}{c}{ Teachers } \\
\cline { 2 - 5 } & $\mathrm{f}$ & & $\mathrm{F}$ & $\%$ \\
\hline $20-25$ & & & 406 & 26.94 \\
$26-30$ & & 3.64 & 183 & 12.14 \\
$31-35$ & 2 & 21.82 & 256 & 16.99 \\
$36-40$ & 12 & 40.00 & 265 & 17.58 \\
$41-45$ & 22 & 34.55 & 196 & 13.67 \\
46 -above & 19 & 100.00 & 1507 & 12.67 \\
\hline Total & 55 & &
\end{tabular}

It tends to be gathered on the table that among the (55) school heads, twenty-two (22) or $40 \%$ of them belonged to 41-45 age group, nineteen (19) or 34.55\% were aged 46-above, twelve (12) or 21.82 belonged to $36-40$, and two (2) or 3.64\% of them were in the age bracket of 31-35.

On the other hand, out of 1507 teachers, 406 or $26.94 \%$ belonged to $20-25$ years old, 265 or $17.58 \%$ were $36-40,256$ or $16.99 \%$ were $31-35$, 206 or 13.67 were $41-45,191$ or $12.67 \%$ were 46 -above, and 183 or 12.14 belonged to $26-30$ years of age bracket.

Table 3. Distribution of the respondents in terms of highest educational attainment

\begin{tabular}{ccccc}
\hline \multirow{2}{*}{ Highest Educational Attainment } & \multicolumn{2}{c}{ School Head } & \multicolumn{2}{c}{ Teachers } \\
\cline { 2 - 5 } & $\mathrm{f}$ & $\%$ & $\mathrm{f}$ & $\%$ \\
\hline Bachelor's Degree & & & 800 & 53.09 \\
BS Degree with Master's Units & 1 & 1.82 & 319 & 21.17 \\
MA Graduate & 28 & 50.91 & 249 & 16.52 \\
MA Degree with Doctorate Units & 16 & 29.09 & 95 & 6.30 \\
Doctorate Degree & 10 & 18.18 & 44 & 2.92 \\
\hline Total & 55 & 100.00 & 1507 & 100.00 \\
\hline
\end{tabular}

Table 3 shows the distribution of the respondents in terms of their highest educational attainment. Twenty-eight (28) or $50.91 \%$ are the highest frequency for school head which is belongs to MA Graduate education bracket, and one (1) or $1.82 \%$ are the lowest frequency which belongs to the BS Degree with Master's units education bracket.

In addition, Eight Hundred (800) or $53.09 \%$ are the highest frequency for variable B which is the teacher and it belongs to Bachelor's Degree education bracket. While, Forty-four (44) or $2.92 \%$ are the lowest frequency which belongs to the Doctorate degree education bracket, which implies that most of the respondents for school head falls to the MA Graduate education bracket and Bachelor's Degree education bracket for teachers.

It can be inferred that the school heads involved in the study were Master's graduates and able to apply what they learned in their graduate school to improve the status of their respective schools while on the part of the part of the teachers it can be stated that they are the ones who need assistance given the fact that they need more knowledge on how they can performed their tasks.

Table 4. Distribution of the respondents in terms of years in service

\begin{tabular}{ccccc}
\hline \multirow{2}{*}{ Years in Service } & \multicolumn{2}{c}{ School Head } & \multicolumn{3}{c}{ Teachers } \\
\cline { 2 - 5 } & $\mathrm{f}$ & $\%$ & $\mathrm{f}$ & $\%$ \\
\hline 10 yrs. and below & 1 & 1.82 & 706 & 46.85 \\
$11-15$ years & 7 & 12.73 & 326 & 21.63
\end{tabular}




\begin{tabular}{ccccc}
$16-20$ years & 18 & 32.73 & 250 & 16.59 \\
$21-25$ years & 17 & 30.91 & 105 & 6.97 \\
26 yrs. and above & 12 & 21.82 & 120 & 7.96 \\
\hline Total & 55 & 100.00 & 1507 & 100.00 \\
\hline
\end{tabular}

Table 4 shows the distribution of respondents in terms of years of service. The majority $(32.73 \%)$ of the school head belongs to the 16-20 years of service. The 21-25 years of service comes next, which gathered $17(30.91 \%)$ of the total respondents. The lowest percentage goes to 10 years of service and below, which only comprises $1(1.82 \%)$ respondent of the total sample population.

Out of 1,507 teachers surveyed, 706 (46.85\%) of them have served 10 years, and below in the school, $326(21.63 \%)$ of them have served 11-15 years in school, $250(16.59 \%)$ teachers served $16-20$ years in the school, $120(7.96 \%)$ teachers have served 26 years and above in school, and 105 (6.97\%) teachers have served at least 21-25 years in school.

The years of service of the respondents are contributory factors to achieving the vision, mission, and goals of the schools. The school head's experience in managing the school can be inferred as one of the considerations in managing the schools.

Table 5. The extent of implementation of the school head's management practices in instruction in terms of designing a vision

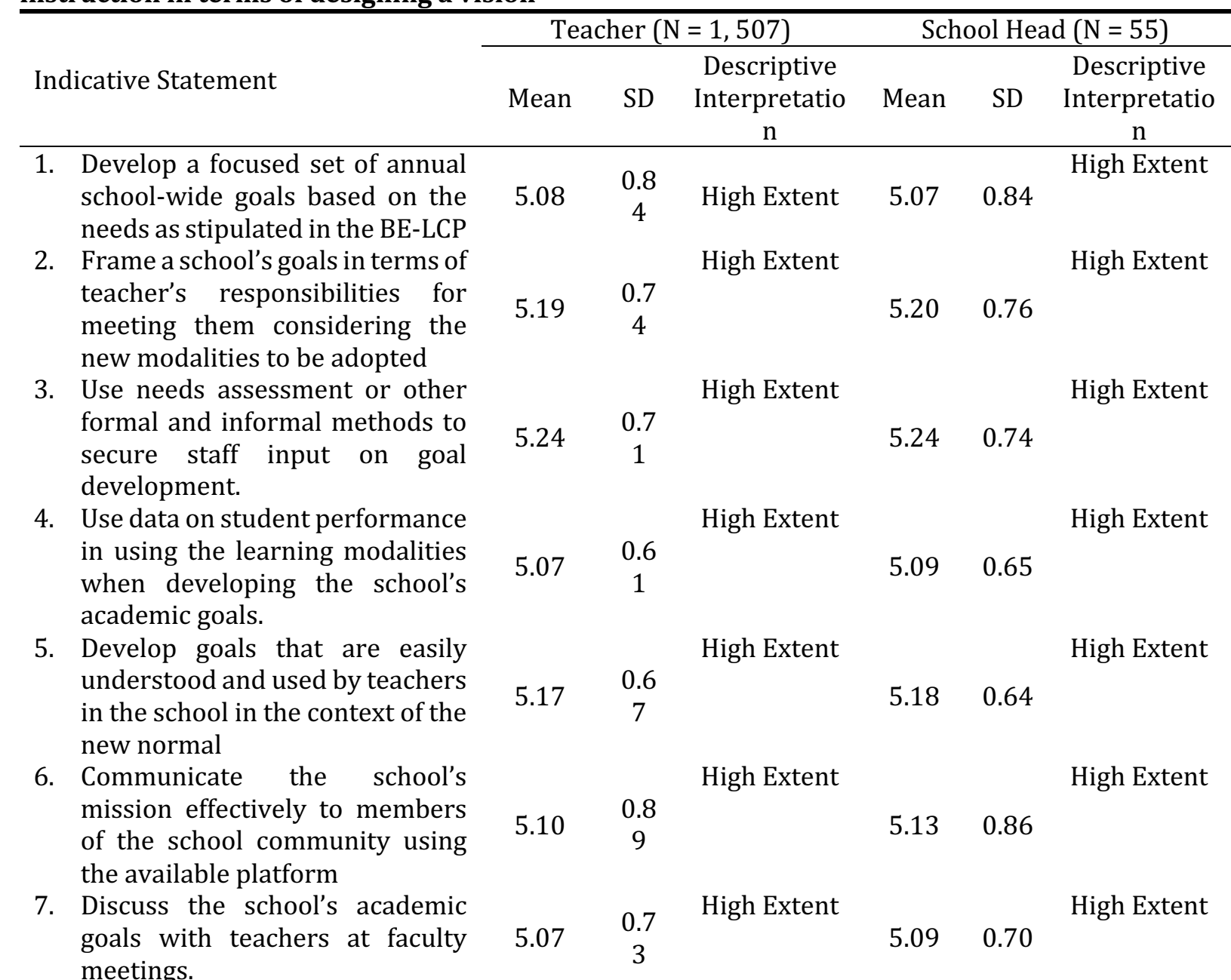


8. Refer to the school's academic goals when making curricular decisions with teachers.

9. Ensure that the school's academic goals are reflected in highly visible displays in the school.

10. Refer to the school's goals or mission in forums with students through the available platforms

$$
\text { Overall }
$$

$4.89 \quad \begin{gathered}1.0 \\ 6\end{gathered}$

High Extent

$4.72 \quad 0.8$

High Extent High Extent

$4.93 \quad 1.03$

High Extent

10.8

2

\begin{tabular}{|c|c|c|c|}
\hline High Extent & 4.64 & 1.04 & High Extent \\
\hline High Extent & 5.03 & 0.29 & High Extent \\
\hline
\end{tabular}

Legend:

5.50 - 6.00 - Always, Great Extent; 4.50 - 5.49 - Almost Always High Extent; 3.50 - 4.49 - Frequently

Moderate Extent 2.50 - 3.49 - Occasionally Low Extent;1.50 - 2.49 - Seldom Least Extent;1.00 - 1.49 Almost Never Not at All

As presented in the table, the means and standard deviations of the teachers' and school heads' responses are almost equal interpreted as high extent. The indicators "Refer to the school's academic goals when making curricular decisions with teachers." , "Ensure that the school's academic goals are reflected in highly visible displays in the school." and "Refer to the school's goals or mission in forms with students through the available platforms." have means of $4.63-4.89$ interpreted as high extent and standard deviations of 0.82 - 1.06. Indicators "Develop a focus set of annual school-wide goals based on the needs as stipulated in the BE-LCP.", "Use data on student performance in using the learning modalities when developing the schools' academic goals.", and "Discuss the school's academic goals with teachers at faculy meetings." have means of 5.07 - 5.08 interpreted as high extent and standard deviations of $0.61-0.84$. Remaining indicators "Frame a school's responsibilities for meeting them considering the new modalities to be adopted." , "Use needs assessment or other formal and informal methods to secure staff input on goal development." "Develop goals that are easily understood and used by teachers in the school in the context of the new normal." and "Communicate the school's mission effectively to - members of the school community using the available platform." have means of 5.10 5.24 interpreted as high extent and standard deviations of $0.64-0.89$.

Overall the means are 5.01 and 5.03 interpreted as high extent with equal standard deviation of 0.29.

The data gathered are manifestations that instructional supervision of the school heads are being done and practiced in the field. The assessment made by

Table 6. Extent of implementation of the school head's management practices in instruction in terms of curriculum and instruction

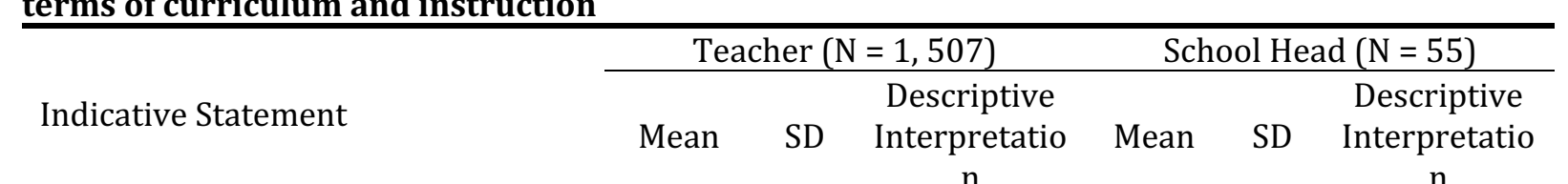

1. Ensure that the classroom priorities of teachers are consistent with the goals and direction of the school as stipulated in the BE-LCP

2. Review student work products when evaluating classroom instruction.

$\begin{array}{cccccc}4.51 & 1.0 & \text { High Extent } & 4.47 & 1.12 & \text { High Extent } \\ & 8 & & & & \\ & & & & & \\ 5.00 & 0.8 & \text { High Extent } & & & \\ & 8 & & 4.98 & 0.93 & \text { High Extent }\end{array}$


3. Conduct informal observations through the modalities adopted by the school.

4. Point out specific strengths in teacher's instructional practices in post-observation feedback.

5. Point out specific weaknesses in teacher instructional practices in post-observation feedback.

6. Make clear who is responsible for coordinating the curriculum across grade levels through proper channelling

7. Draw upon the results of the assessment provided when making curricular decisions.

8. Monitor the classroom curriculum to see that it covers the school's curricular objectives.

9. Assess the overlap between the school's curricular objectives and the school's achievement tests.

10. Participate actively in the review of curriculum materials.

\begin{tabular}{|c|c|c|c|c|c|}
\hline 5.14 & $\begin{array}{c}0.7 \\
9\end{array}$ & High Extent & 5.11 & 0.83 & High Extent \\
\hline 87 & $\begin{array}{c}0.8 \\
0\end{array}$ & High Extent & 4.91 & 0.80 & High Extent \\
\hline .11 & $\begin{array}{c}0.7 \\
2\end{array}$ & High Extent & 5.09 & 0.75 & High Extent \\
\hline 10 & 0.8 & High Extent & 5.11 & 0.85 & High Extent \\
\hline
\end{tabular}

0.7 High Extent

$5.05 \quad 0.78$ High Extent

High Extent

4.60 1.18 High Extent

High Extent

$\begin{array}{lcccc}4.56 & 0.8 & 4.58 & 0.85 & \text { High Extent }\end{array}$

\begin{tabular}{ccccccc} 
of curriculum materials. & 4.54 & 1 & & 4.56 & 1.01 & High Extent \\
\hline Overall & 4.84 & $\begin{array}{c}0.2 \\
9\end{array}$ & High Extent & 4.85 & 0.29 & High Extent \\
\hline
\end{tabular}

Legend:

5.50 - 6.00 - Always, Great Extent;4.50 - 5.49 - Almost Always High Extent; 3.50 - 4.49 - Frequently

Moderate Extent 2.50 - 3.49 - Occasionally Low Extent;1.50 - 2.49 - Seldom Least Extent;1.00 - 1.49 -

Almost Never Not at All

Table 6 shows that the means and standard deviations of the teachers' and school heads' responses are almost equal and interpreted to as high extent. The indicators "Ensure that the classroom priorities of teachers are consistent with the goals and direction of the school as stipulated in the BELCP.", "Point out specific strengths in teacher's instructional practices in post-observation feedback." , "Monitor the classroom curriculum to see that it covers the school's curricular objectives." , "Assess the overlap between the school's curricular objectives and the school's achievement tests." and "Participate actively in the review of curriculum materials." have means of $4.51-4.87$ interpreted as high extent and standard deviations of $0.80-1.20$. Indicators "Review student work products when evaluating classroom instruction.", "Conduct informal observations through the modalities adopted by the school.", "Point out specific weaknesses in teacher instructional practices in post-observation feedback.", "Make clear who is responsible for coordinating the curriculum across grade levels through proper channeling." and "Draw upon the results of the assessment provided when making curricular decisions." have means of 4.98 - 5.14 interpreted as high extent and standard deviations of $0.72-0.93$. Overall the means are 4.84 and 4.85 interpreted as high extent with an equal standard deviation of 0.29 .

Table 7. The extent of implementation of the school head's management practices in instruction in terms of supervising teachers

\begin{tabular}{lllllll}
\hline \multirow{2}{*}{ Indicative Statement } & \multicolumn{2}{c}{ Teacher $(\mathrm{N}=1,507)$} & \multicolumn{2}{c}{ School Head (N = 55) } \\
\cline { 2 - 5 } & Mean & SD & Descriptive & Mean & SD & Descriptive \\
\cline { 2 - 5 }
\end{tabular}




\begin{tabular}{|c|c|c|c|c|c|c|}
\hline & & & $\begin{array}{c}\text { Interpretatio } \\
\mathrm{n}\end{array}$ & & & $\begin{array}{c}\text { Interpretatio } \\
\mathrm{n}\end{array}$ \\
\hline $\begin{array}{l}\text { 1. Reinforce superior performance } \\
\text { by teachers in staff meetings, } \\
\text { newsletters, and/or memos. }\end{array}$ & 5.10 & $\begin{array}{c}0.8 \\
0\end{array}$ & High Extent & 5.07 & 0.84 & High Extent \\
\hline $\begin{array}{l}\text { 2. Compliment teachers privately } \\
\text { for their effort or performance. }\end{array}$ & 5.20 & $\begin{array}{c}0.7 \\
2\end{array}$ & High Extent & 5.20 & 0.76 & High Extent \\
\hline $\begin{array}{l}\text { 3. Acknowledge } \\
\text { exceptional performance by } \\
\text { writing }\end{array}$ & 5.24 & $\begin{array}{c}0.7 \\
1\end{array}$ & High Extent & 5.24 & 0.74 & High Extent \\
\hline $\begin{array}{l}\text { 4. Reward special efforts by } \\
\text { teachers with opportunities for } \\
\text { professional recognition. }\end{array}$ & 4.97 & $\begin{array}{c}0.7 \\
0\end{array}$ & High Extent & 4.98 & 0.73 & High Extent \\
\hline $\begin{array}{l}\text { 5. Create professional growth } \\
\text { opportunities for teachers as a } \\
\text { reward for special contributions } \\
\text { to the school. }\end{array}$ & 5.18 & $\begin{array}{c}0.6 \\
4\end{array}$ & High Extent & 5.18 & 0.64 & High Extent \\
\hline $\begin{array}{l}\text { 6. Ensure that in-service activities } \\
\text { attended by the staff are } \\
\text { consistent with the school's } \\
\text { goals. }\end{array}$ & 5.10 & $\begin{array}{c}0.8 \\
9\end{array}$ & High Extent & 5.13 & 0.86 & High Extent \\
\hline $\begin{array}{l}\text { 7. Actively support the use in the } \\
\text { classroom of skills acquired } \\
\text { during in-service training. }\end{array}$ & 5.06 & $\begin{array}{c}0.6 \\
7\end{array}$ & High Extent & 5.05 & 0.68 & High Extent \\
\hline $\begin{array}{l}\text { 8. Obtain the participation of the } \\
\text { whole staff in important in } \\
\text { service activities }\end{array}$ & 4.89 & $\begin{array}{c}1.0 \\
6\end{array}$ & High Extent & 4.93 & 1.03 & High Extent \\
\hline $\begin{array}{l}\text { 9. Lead or attend teacher in-service } \\
\text { activities concerned with } \\
\text { instruction. }\end{array}$ & 4.72 & $\begin{array}{c}0.8 \\
2\end{array}$ & High Extent & 4.73 & 0.85 & High Extent \\
\hline $\begin{array}{l}\text { 10. Set aside time at faculty meetings } \\
\text { for teachers to share ideas or } \\
\text { information from in service } \\
\text { activities. }\end{array}$ & 4.78 & $\begin{array}{c}0.9 \\
8\end{array}$ & High Extent & 4.75 & 0.99 & High Extent \\
\hline Overall & 5.02 & $\begin{array}{c}0.2 \\
8\end{array}$ & High Extent & 5.03 & 0.30 & High Extent \\
\hline
\end{tabular}

Legend:

5.50 - 6.00 - Always, Great Extent;4.50 - 5.49 - Almost Always High Extent; 3.50 - 4.49 - Frequently Moderate Extent 2.50 - 3.49 - Occasionally Low Extent;1.50 - 2.49 - Seldom Least Extent;1.00 - 1.49 Almost Never Not at All

As shown in the table, the means and standard deviations of the teachers' and school heads' responses are almost equal interpreted as high extent. The indicators "Reward special efforts by teachers with opportunities for professional recognition." , "Obtain the participation of the whole staff in important in service activities." , "Lead or attend teacher in service activities concerned with instruction." and "Set aside time at faculty meetings for teachers to share ideas or information from in service activities." have means of $4.72-4.98$ interpreted as high extent and standard deviations of $0.70-1.06$. Indicators "Reinforce superior performance by teachers in staff meetings, newsletters, and/or memos." , "Create professional growth opportunities for teachers as a reward for special contributions to the school." , "Ensure that in service activities attended by the staff are consistent with the school's goals." and "Actively support the use in the classroom of skills acquired during in service training." have means of $5.10-5.18$ interpreted as high extent and standard deviations of $0.64-0.89$. Other indicators, "Compliment teachers privately for their effort or performance." and "Acknowledge teacher's 
exceptional performance by writing." have means of 5.20 and 5.24 interpreted as high extent and standard deviations of $0.71-0.76$. Overall the means are 5.02 and 5.03, interpreted as high extent with standard deviations of 0.28 and 0.30 .

Table 8. Extent of implementation of the school head's management practices in instruction in terms of monitoring student progress

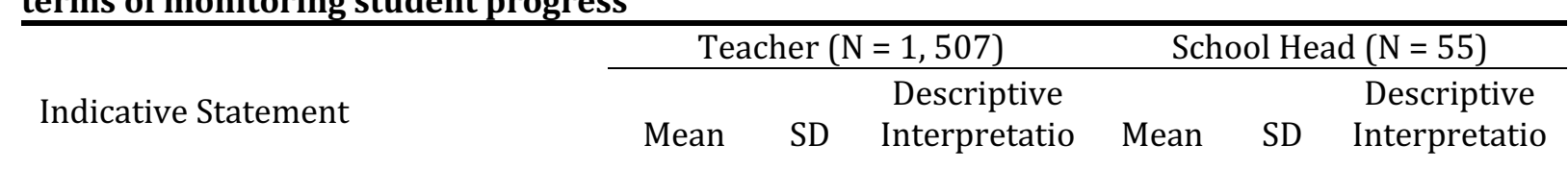

1. Take time to talk informally with students and teachers through the feedback mechanism stipulated in the LCP.

2. Attend to the class using the link provided to ensure that instruction is delivered following the screen time

3. Provide direct instructions to classes when the need arises, specifically if a connection is concerned.

4. Meet individually with teachers to discuss student progress through the mechanism provided by the school.

5. Discuss academic performance results with the faculty to identify curricular strengths and weaknesses.

6. Use tests and another performance measure to assess progress toward school goals.

7. Inform teachers of the school's performance results in written form.

$\begin{array}{ccc}5.21 & 0.7 & \text { High Extent } \\ & 0 & \\ & & \text { High Extent } \\ 5.07 & 0.6 & \end{array}$

$\begin{array}{lccc}5.07 & 0.6 & 5.09 & 0.65\end{array}$ High Extent

\begin{tabular}{|c|c|c|c|}
\hline & & & \\
\hline 5.18 & $\begin{array}{c}0.6 \\
4\end{array}$ & 5.18 & 0.64 \\
\hline
\end{tabular}

High Extent

$\begin{array}{ccccc}5.10 & 0.8 & 5.13 & 0.86 & \text { High Extent }\end{array}$

8. Inform students of school's academic progress following the DepEd Orders

\begin{tabular}{rcccccc}
\hline Overall & 5.01 & $\begin{array}{c}0.3 \\
2\end{array}$ & High Extent & 5.03 & 0.34 & High Extent \\
\hline
\end{tabular}

Legend:

5.50 - 6.00 - Always, Great Extent; 4.50 - 5.49 - Almost Always High Extent; 3.50 - 4.49 - Frequently Moderate Extent 2.50 - 3.49 - Occasionally Low Extent;1.50 - 2.49 - Seldom Least Extent;1.00 - 1.49 Almost Never Not at All

As represented in the Table, both teachers and school heads in terms of monitoring student progress, got an overall mean of 5.01 and 5.03 respectively, interpreted as high extent, and standard deviation of 0.32 and 0.34 respectively. Meaning, the table under monitoring student progress reflected that all the indicative statements were almost performed. The indicator "Take time to talk informally with students and teachers through the feedback mechanism stipulated in the LCP." got the highest mean both from teachers 5.21 and school heads 5.22, having a standard deviation of 0.70 and 0.74 
respectively, meaning the voice of customers are essential in monitoring the learner's progress properly.

Table 9. Extent of implementation of the school head's management practices in instruction in terms of protecting the instructional climate

\begin{tabular}{|c|c|c|c|c|c|c|}
\hline \multirow[b]{2}{*}{ Indicative Statement } & \multicolumn{3}{|c|}{ Teacher $(\mathrm{N}=1,507)$} & \multicolumn{3}{|c|}{ School Head (N = 55) } \\
\hline & Mean & SD & $\begin{array}{c}\text { Descriptive } \\
\text { Interpretatio } \\
\mathrm{n}\end{array}$ & Mean & SD & $\begin{array}{c}\text { Descriptive } \\
\text { Interpretatio } \\
\mathrm{n}\end{array}$ \\
\hline $\begin{array}{l}\text { 1. Limit interruptions } \text { of } \\
\text { instructional time by public } \\
\text { address. }\end{array}$ & 5.20 & $\begin{array}{c}0.7 \\
2\end{array}$ & High Extent & 5.20 & 0.76 & High Extent \\
\hline $\begin{array}{l}\text { 2. Encourage teachers to use the } \\
\text { instructional time for teaching } \\
\text { and practicing new skills and } \\
\text { concepts. }\end{array}$ & 5.24 & $\begin{array}{c}0.7 \\
1\end{array}$ & High Extent & 5.24 & 0.74 & High Extent \\
\hline $\begin{array}{l}\text { 3. Limit the intrusion of extra- and } \\
\text { co-curricular activities on } \\
\text { instructional time. }\end{array}$ & 5.07 & $\begin{array}{c}0.6 \\
1\end{array}$ & High Extent & 5.09 & 0.65 & High Extent \\
\hline $\begin{array}{l}\text { 4. Recognize students who } \\
\text { superior work with formal } \\
\text { rewards such as an honor roll or } \\
\text { mention in the principal's } \\
\text { newsletter. }\end{array}$ & 5.20 & $\begin{array}{c}0.6 \\
5\end{array}$ & High Extent & 5.20 & 0.65 & High Extent \\
\hline $\begin{array}{l}\text { 5. Use online assemblies to honor } \\
\text { students for academic } \\
\text { accomplishments or for } \\
\text { academic behaviour or } \\
\text { citizenship. }\end{array}$ & 5.10 & $\begin{array}{c}0.8 \\
9\end{array}$ & High Extent & 5.13 & 0.86 & High Extent \\
\hline $\begin{array}{l}\text { 6. Recognize superior student } \\
\text { achievement or improvement by } \\
\text { seeing in the office the students } \\
\text { with their work. }\end{array}$ & 5.07 & $\begin{array}{c}0.7 \\
1\end{array}$ & High Extent & 5.07 & 0.72 & High Extent \\
\hline $\begin{array}{l}\text { 7. Contact parents to communicate } \\
\text { improved or exemplary student } \\
\text { performance or contributions. }\end{array}$ & 4.89 & $\begin{array}{c}1.0 \\
6\end{array}$ & High Extent & 4.93 & 1.03 & High Extent \\
\hline $\begin{array}{l}\text { 8. Support teachers actively in their } \\
\text { recognition and/or reward of } \\
\text { student contributions to and } \\
\text { accomplishments in class. }\end{array}$ & 4.72 & $\begin{array}{c}0.8 \\
2\end{array}$ & High Extent & 4.73 & 0.85 & High Extent \\
\hline Overall & 5.01 & $\begin{array}{c}0.3 \\
2\end{array}$ & High Extent & 5.08 & 0.32 & High Extent \\
\hline
\end{tabular}

Legend:

5.50 - 6.00 - Always, Great Extent; 4.50 - 5.49 - Almost Always High Extent; 3.50 - 4.49 - Frequently Moderate Extent 2.50 - 3.49 - Occasionally Low Extent;1.50 - 2.49 - Seldom Least Extent;1.00 - 1.49 Almost Never Not at All

As represented in the Table, both teachers and school heads, in terms of protecting the instructional climate, got an overall mean of 5.01 and 5.08 respectively, interpreted as high extent, and standard deviation both of 0.32 .

The indicator "Encourage teachers to use instructional time for teaching and practicing new skills and concepts" showed the highest mean of 5.24 both from teachers and the school heads, with a standard 
deviation of 0.71 and 0.74 , respectively. Significantly, the teachers and the school heads are highly committed to protecting the instructional climate among learners through innovations and acquisitions of new skills and concepts.

\section{Table 10. Level of teacher's organizational behavior in terms of organizational commitment}

\begin{tabular}{|c|c|c|c|}
\hline Indicative Statement & Mean & SD & $\begin{array}{l}\text { Descriptive } \\
\text { Interpretation }\end{array}$ \\
\hline 1. I really care for the fate of this school & 5.11 & 0.80 & Committed \\
\hline 2. I do not feel like "part of the family" at the school.* & 4.00 & 1.03 & $\begin{array}{l}\text { Moderately } \\
\text { Committed }\end{array}$ \\
\hline 3. I do not feel "emotionally attached" to this school.* & 3.75 & 1.20 & $\begin{array}{l}\text { Moderately } \\
\text { Committed }\end{array}$ \\
\hline $\begin{array}{l}\text { 4. I do not feel a strong sense of belonging to the } \\
\text { school.* }\end{array}$ & 4.01 & 0.94 & $\begin{array}{l}\text { Moderately } \\
\text { Committed }\end{array}$ \\
\hline $\begin{array}{l}\text { 5. I would be very happy to spend the rest of my } \\
\text { career in this school. }\end{array}$ & 4.87 & 0.73 & Committed \\
\hline 6. I really feel as if this school's problems are my own. & 4.98 & 0.94 & Committed \\
\hline $\begin{array}{l}\text { 7. This school has a great deal of personal meaning for } \\
\text { me }\end{array}$ & 4.97 & 0.77 & Committed \\
\hline $\begin{array}{l}\text { 8. Deciding to work for this school was a definite } \\
\text { mistake on my part. }\end{array}$ & 5.04 & 0.76 & Committed \\
\hline Mean & 4.59 & 0.45 & Committed \\
\hline
\end{tabular}

Legend:

5.50 - 6.00 - Always, Great Extent;4.50 - 5.49 - Almost Always High Extent; 3.50 - 4.49 - Frequently

Moderate Extent 2.50 - 3.49 - Occasionally Low Extent;1.50 - 2.49 - Seldom Least Extent;1.00 - 1.49 -

Almost Never Not at All

It can be gleaned in the table that the overall level of teachers' organizational behavior in terms of organizational commitment was 4.59 with SD of 0.45 and verbally interpreted as "committed."

Among the indicators presented, "Deciding to work for this school was a definite mistake on my part" got the highest mean of 5.04 which is interpreted as "committed" and standard deviation of 0.76 , The indicator "I really care for the fate of this school" has a mean of 5.11 interpreted as committed and standard deviation of 0.80 . The indicator "I really feel as if this school's problems are my own" has a mean of 4.98 interpreted as committed with a standard deviation of 0.94 . The indicator "This school has a great deal of personal meaning for me" has a mean of 4.97 and is interpreted as committed with a standard deviation of 0.77 . The indicator "I would be very happy to spend the rest of my career in this school" has a mean of 4.87, interpreted as committed with a standard deviation of 0.73 . The indicator "I do not feel a strong sense of belonging to the school.*" has a mean of 4.01 interpreted as moderately committed with a standard deviation of 0.94. The indicator "I do not feel like "part of the family" at the school." has a mean of 4.0 interpreted as moderately committed and a standard deviation of 1.03. The indicator "I do not feel "emotionally attached" to this school.*" has a 3.75 weighted mean interpreted as moderately committed and a standard deviation of 1.25 .

This means that the teachers manifested a commitment to their organizational behaviour. This is really essential in order for the goals and objectives will be achieved since one of the characteristics needed to sustain the institutional goal is to have people who can commit themselves to the total development of the institution.

Table 11. Level of teacher's organizational behavior in terms of professional commitment Indicative Statement

Mean

SD 
1. Too much of my life would be disrupted if I decided to leave school right now, even if I wanted to.

$3.33 \quad 1.02 \quad$ Quite Committed

2. I believe that I have too few options to consider leaving this school.

3. One of the few negative consequences of leaving this school would be the lack of available alternatives.

4. If I had not already put so much of myself into this school, I might consider working elsewhere.

$\begin{array}{lll}4.83 & 0.94 \quad \text { Committed }\end{array}$

$3.27 \quad 1.11 \quad$ Quite Committed

$3.31 \quad 1.10 \quad$ Quite Committed

5. It would be very hard for me to leave this school right now, even if I wanted to.

3.07 $1.05 \quad$ Quite Committed

6. I wish I leave this school. *

7. I work for this school only as long as I have no other option

$\begin{array}{lll}4.62 & 1.04 \quad \text { Committed }\end{array}$

$3.42 \quad 1.14 \quad$ Quite Committed

3.69

0.68

Moderately

Committed

Legend:

5.50 - 6.00 - Always, Great Extent;4.50 - 5.49 - Almost Always High Extent; 3.50 - 4.49 - Frequently

Moderate Extent 2.50 - 3.49 - Occasionally Low Extent;1.50 - 2.49 - Seldom Least Extent;1.00 - 1.49 -

Almost Never Not at All

As presented in the table, the overall mean of the professional commitment of teachers is 3.69 , interpreted as moderately committed and standard deviation of 0.68 . The indicator "I believe that I have too few options to consider leaving this school" has a mean of 4.83 interpreted as committed and a standard deviation of 0.94 . The indicator "I wish I leave this school.*" has a mean of 4.62 interpreted as committed and a standard deviation of 1.04. The indicators "I work for this school only as long as I have no other option", "Too much of my life would be disrupted if I decided to leave the school right now, even if I wanted to", "If I had not already put so much of myself into this school, I might consider working elsewhere", "One of the few negative consequences of leaving this school would be the lack of available alternatives", "It would be very hard for me to leave this school right now, even if I wanted to", were assessed by the respondents as quite committed with the mean of 3.42, 3.33, 3.31, 3.27, and 3.07 respectively and standard deviation of $1.14,1.02,1.10,1.11$, and 1.05 .

Table 12. Level of teacher's organizational behavior in terms of organizational citizenship behavior

\begin{tabular}{|c|c|c|c|}
\hline Indicative Statement & Mean & SD & $\begin{array}{l}\text { Descriptive } \\
\text { Interpretation }\end{array}$ \\
\hline $\begin{array}{l}\text { 1. I do not feel any obligation to remain with my } \\
\text { current employer.* }\end{array}$ & 3.71 & 1.24 & $\begin{array}{l}\text { Moderately } \\
\text { Committed }\end{array}$ \\
\hline 2. I would feel guilty if I left the school now. & 4.48 & 1.22 & $\begin{array}{l}\text { Moderately } \\
\text { Committed }\end{array}$ \\
\hline 3. This school deserves my loyalty. & 4.99 & 0.73 & Committed \\
\hline $\begin{array}{l}\text { 4. I would not leave my school right now because I } \\
\text { have a sense of obligation to the people in it. }\end{array}$ & 5.11 & 0.85 & Committed \\
\hline $\begin{array}{l}\text { 5. Even if it were to my advantage, I do not feel it } \\
\text { would be right to leave the school now. }\end{array}$ & 5.09 & 0.69 & Committed \\
\hline $\begin{array}{l}\text { 6. Right now, staying with this school is a matter of } \\
\text { contract.* }\end{array}$ & 3.65 & 1.15 & $\begin{array}{l}\text { Moderately } \\
\text { Committed }\end{array}$ \\
\hline Mean & 4.51 & 0.45 & Committed \\
\hline
\end{tabular}


As illustrated in the table, the levels of teachers' organizational behaviour in terms of organizational citizenship behavior obtained the total mean of 4.51 with a standard deviation of 0.45 and descriptively interpreted as committed.

Among the indicators, "This school deserves my loyalty", "I would not leave my school right now because I have a sense of obligation to the people in it", and "I would not leave my school right now because I have a sense of obligation to the people in it" got the same verbal interpretation of committed with 4.99, 5.11 and 5.09 mean respectively and $0.73,0.85$ and 0.69 standard deviations.

On the other hand, the other indicators such as "I would feel guilty if I left the school now", "I do not feel any obligation to remain with my current employer.", and "Right now, staying with this school is a matter of contract." were interpreted as moderately committed. The mean obtained were 4.48, 3.71, and 3.65, respectively, with the standard deviation of $1.24,1.22$, and 1.15 .

Table 13. Level of teacher's organizational behavior in terms of job involvement

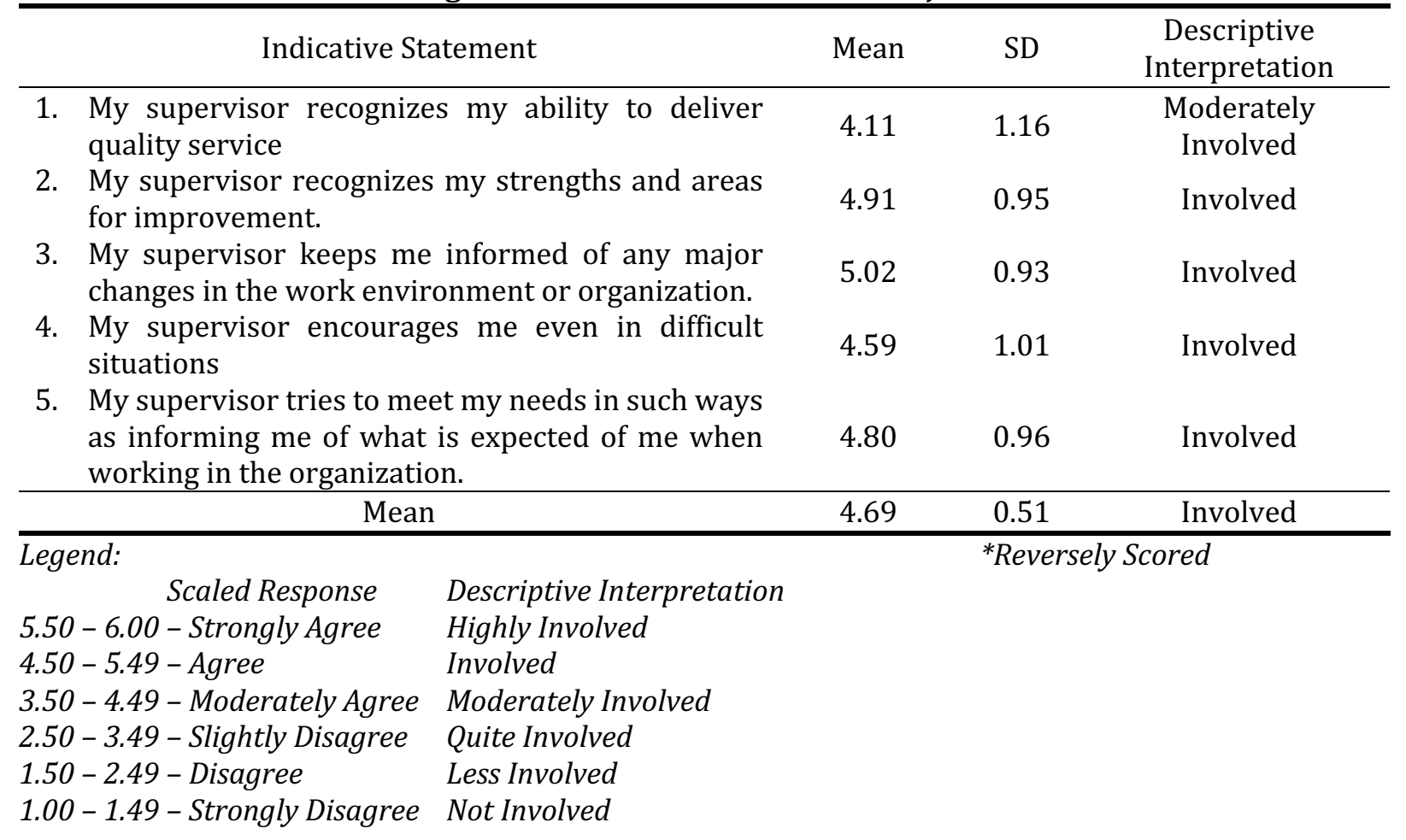

As illustrated in table 13, the overall assessment to the level of teachers' organizational behavior in terms of job involvement is 4.69 and interpreted as involved.

Four indicators were descriptively interpreted as involved. Among those are "My supervisor keeps me inform of any major changes in the work environment or organization", "My supervisor recognizes my strengths and areas for improvement", "My supervisor tries to meet my needs in such ways as informing me of what is expected of me when working in the organization", and "My supervisor encourages me even in difficult situations" and these got the mean of 5.02, 4.91, 4.80 and 4.59 respectively. The standard deviations obtained were $0.93,0.95,0.96$, and 1.01. Meanwhile, indicator "My supervisor recognizes my ability to deliver quality service" got 4.11 mean and 1.16 standard deviation with moderately involved as verbal interpretation. 
Table 14. Level of teacher's performance in terms of social presence

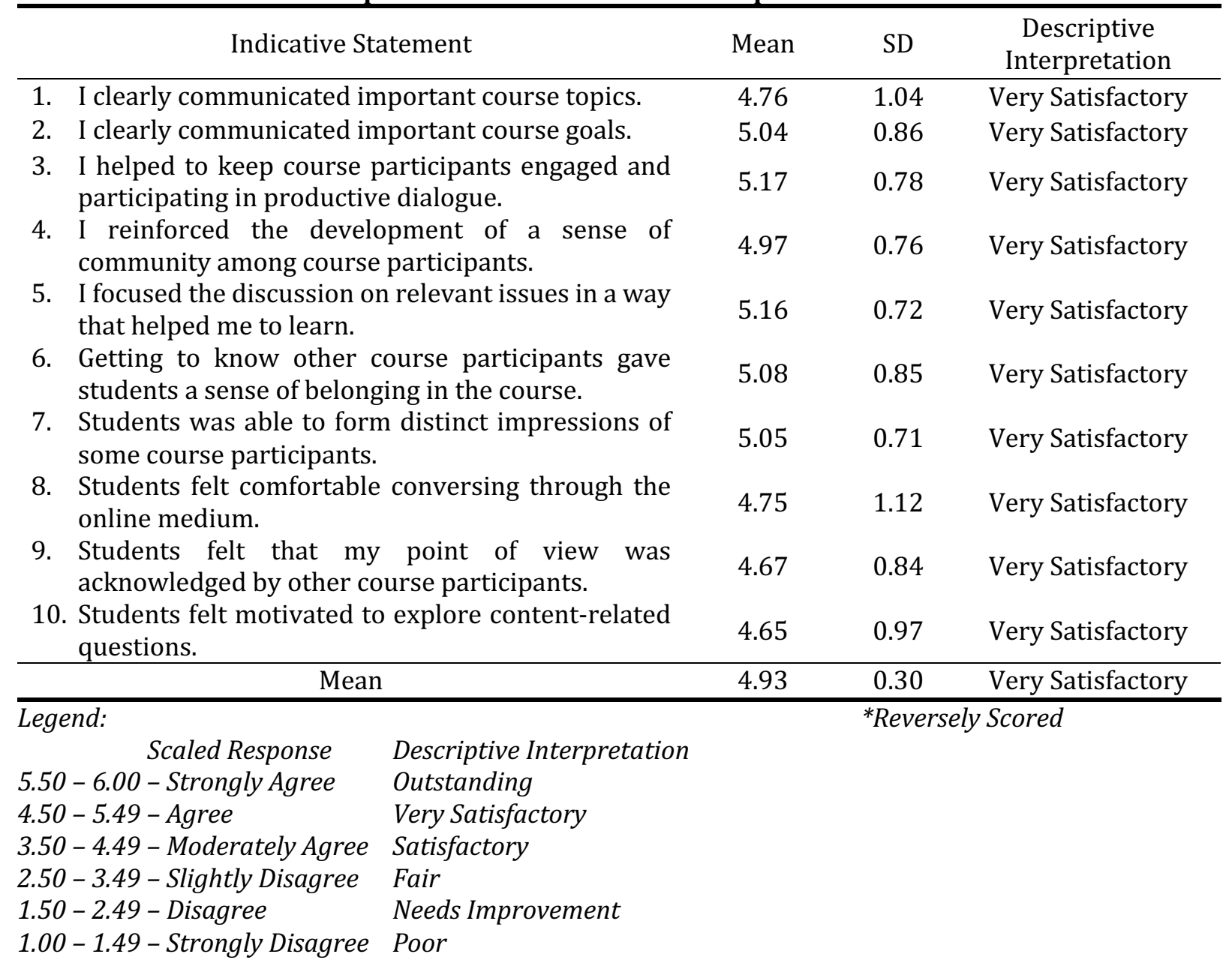

Table 14 presents that the Level of teacher's performance in terms of social presence has a mean of 4.93 with a verbal interpretation of Very Satisfactory (VS). The highest mean for teacher's performance in terms of social presence is indicator \#5, "I helped to keep course participants engaged and participating in productive dialogue," has a mean of 5.17 with the verbal interpretation of Very Satisfactory, on the other hand the least indicators of teacher's performance in terms of social presence is "students felt motivated to explore content related questions with 4.65 a verbal interpretation of very satisfactory.

Teacher's social presence states clearly that teachers want to engage, collaborate in the productive dialogue to deliver their teaching effectively and to add their ideas, techniques, approaches in the instruction process.

The researcher has since a long time ago attempted to clarify people's social practices in online conditions, and social presence is one of the key logical developments in these endeavors. Social presence is thought to assume a supporting part in the development of connections and the trading of data inside an interceded climate. That social presence is essential to connection, and learning can be valued by an appeal to constructivist standards.

Table 15. Level of teacher's performance in terms of cognitive presence 


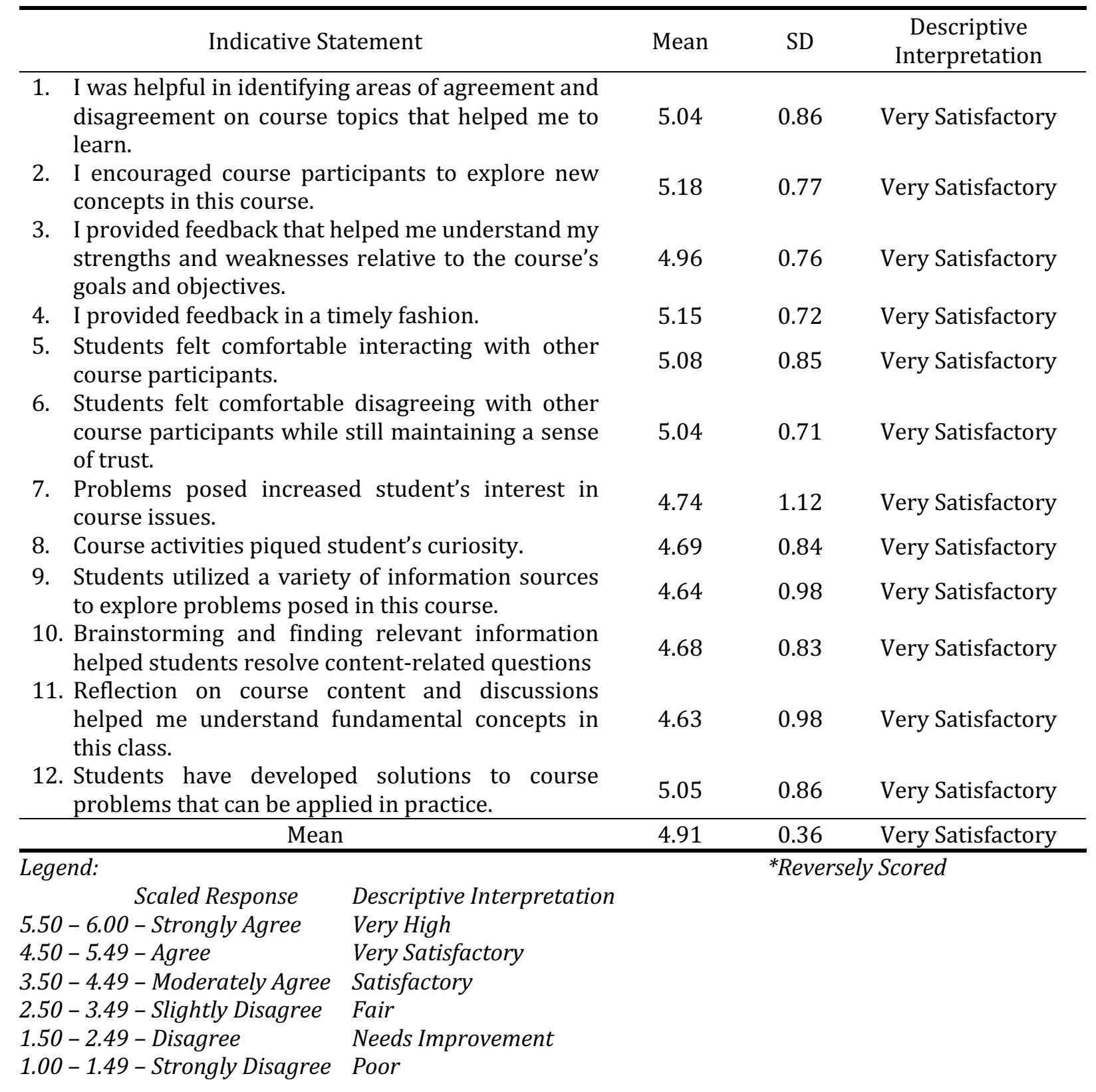

Table 15 shows the level of teacher's performance in terms of cognitive presence, where the scaled response of 5.50-6.00 means strongly agree and scale 1.00-1.49 refers to strongly disagree. For descriptive interpretation, scale 5.50-6.00 being very high, and scale 1.00-1.49 being the poor.

The highest indicator revealed in "I encouraged course participants to explore new concepts in this course" is 5.18 with verbal interpretation of VS, while the least mean reveals in "Reflection on course content and discussions helped understand fundamental concepts in this class" with 4.63 (Very Satisfactory).

With the average mean of 4.91 and standard deviation of 0.36 , agree as scaled response and very satisfactory as descriptive interpretation, the table clearly shows that learners are able to construct ideas and to engage more in terms of the cognitive presence of the teachers.

Teachers need to assist or guide in the simplest to complex concepts to understand better and apply them in the field. 
Table 16. Level of teacher's performance in terms of teaching presence

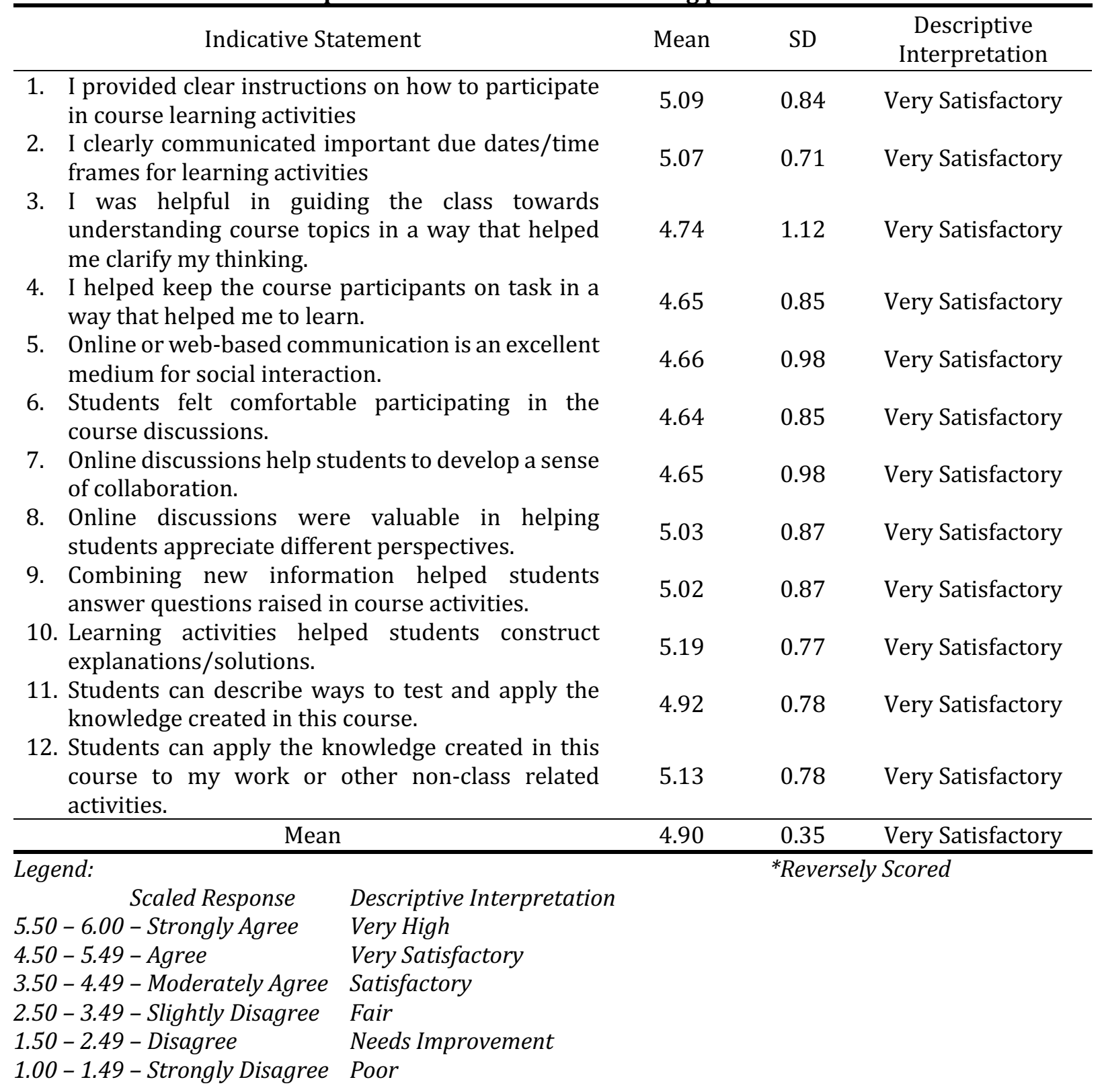

Table 16 The information reveals the level of teacher's performance in terms of teaching presence, wherein the mean performance of the teachers in teaching presence was "Very Satisfactory" with an average of 4.90 and a standard deviation of 0.35 .

The highest mean is 5.19 reveals In the "Learning activities helped students construct explanations/ solutions" with a verbal interpretation of Very Satisfactory, the least mean reveals with 4.64 in the "students felt comfortable participating in the course discussions "has a verbal interpretation of very satisfactory.

In addition, the indicative statement that got the highest mean which is 5.19 is statement 10 , while 4.64 is the lowest mean which is the statement 6 . It reveals that teachers who give learning activities help students construct explanations/solutions. 
It is clearly stated the students are learning with peers or groups by sharing or collaborating their ideas. It is also manifested that students are not independent to deliver their thoughts in the discussion.

Table 17. Test of the significant relationship between the management practices of school heads and the teachers' organizational behavior

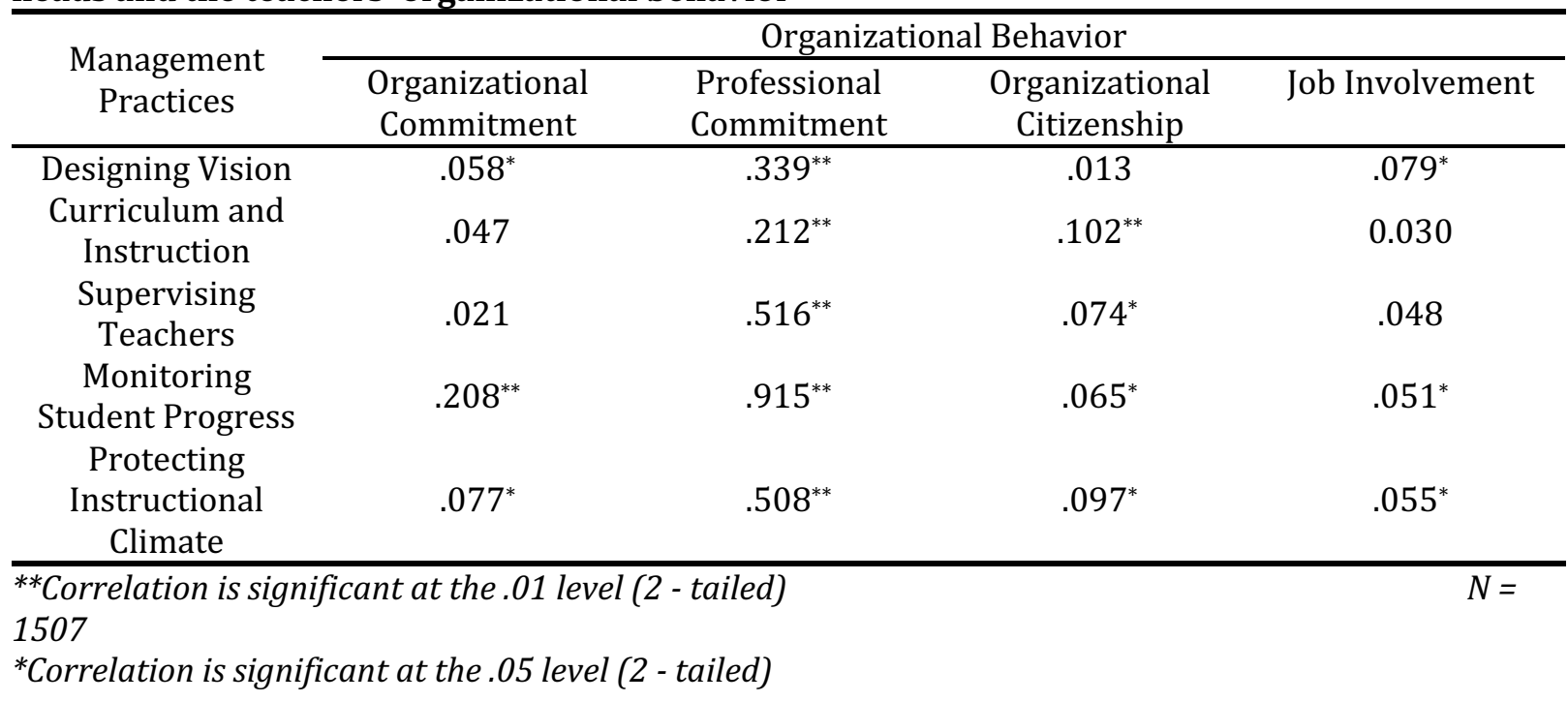

Table 17 presents the correlation results between the management practices of school heads and teachers' organizational behavior. It could be gleaned on the table that the organizational behavior in terms of organizational commitment is positively and significantly related to designing vision $(\mathrm{r}=$ $.058 ; \mathrm{p}<.05)$ and protecting instructional climate $(\mathrm{r}=.077 ; \mathrm{p}<.05)$, and students' progress $(\mathrm{r}=.208$; $\mathrm{p}<.01)$.

On the other hand, in terms of professional commitment, positive and high significant relationship was noted at .01 level of significance along designing vision ( $\mathrm{r}=.339)$, Curriculum and Instruction ( $\mathrm{r}$ $=.212)$, supervising teachers $(\mathrm{r}=.516)$, monitoring students' progress $(.915)$, protecting instructional climate (.508).

In terms of organizational Citizenship, a significant relationship between curriculum and instruction $(r=.102)$ was noted at 0.05 level of significance while in terms of supervising teachers $(r=.074)$, monitoring students' progress $(\mathrm{r}=.065)$, and protecting instructional climate $(\mathrm{r}=.097)$, positive and significant relationship was noted at 0.01 level of significance.

It can be inferred in the data gathered that the management practices of school heads are associated to the teachers' organizational behavior. The practices of the school heads are being done to improve the existing situations in the school.

Table 18. Test of significant relationship between the management practices of school heads and the level of teachers' performance

\begin{tabular}{cccc}
\hline \multirow{2}{*}{ Management Practices } & \multicolumn{3}{c}{ Teacher's Performance } \\
\cline { 2 - 4 } & Social Presence & Cognitive Presence & Teaching Presence \\
\hline Designing Vision & $.104^{* *}$ & $.111^{* *}$ & $.111^{* *}$ \\
Curriculum and & $.060^{*}$ & $.068^{*}$ & $.089^{*}$
\end{tabular}




\begin{tabular}{|c|c|c|c|}
\hline Supervising Teachers & $.220^{* *}$ & $.274^{* *}$ & $.278^{* *}$ \\
\hline $\begin{array}{l}\text { Monitoring Student } \\
\text { Progress }\end{array}$ & $.758^{* *}$ & $.706^{* *}$ & $.682^{* *}$ \\
\hline $\begin{array}{c}\text { Protecting } \\
\text { Instructional Climate }\end{array}$ & $.474^{* *}$ & $.601^{* *}$ & $.575^{* *}$ \\
\hline
\end{tabular}

Based on the table, the teachers performance in terms of social presence along designing vision ( $\mathrm{r}$ $=.104)$, supervising teachers $(\mathrm{r}=.220)$, monitoring students progress $(\mathrm{r}=.706)$, and protecting instructional climate ( $\mathrm{r}=.474)$ was highly significant with management practices at .01 level of significant while curriculum and instruction $(.060)$ was significant at .05 level.

In terms of cognitive presence, designing vision (.111), supervising teachers (.274), monitoring student progress (.706), and protecting instructional climate (.601) were highly significant at .01 level while curriculum and instruction (.068) were highly significant at .05 level.

Moreover, the performance in terms of teaching presence along with designing vision (.111), supervising teachers (.278), monitoring students' progress (.682), and protecting instructional climate (.575) were highly significant at .01 level while curriculum and instruction (.089) was significant at .05 level.

Table 19. Test of significant relationship between the teachers' organizational behavior and teaching performance

\begin{tabular}{|c|c|c|c|}
\hline \multirow{2}{*}{$\begin{array}{l}\text { Organizational } \\
\text { Behavior }\end{array}$} & \multicolumn{3}{|c|}{ Teacher's Performance } \\
\hline & Social Presence & Cognitive Presence & Teaching Presence \\
\hline $\begin{array}{l}\text { Organizational } \\
\text { Commitment }\end{array}$ & $.225^{* *}$ & $.394^{* *}$ & $.426^{* *}$ \\
\hline $\begin{array}{l}\text { Professional } \\
\text { Commitment }\end{array}$ & $.789^{* *}$ & $.851^{* *}$ & $.847^{* *}$ \\
\hline $\begin{array}{l}\text { Organizational } \\
\text { Citizenship }\end{array}$ & $.088^{*}$ & $.175^{* *}$ & $.193^{* *}$ \\
\hline Job Involvement & $.112^{* *}$ & $.088^{*}$ & $.120^{* *}$ \\
\hline
\end{tabular}

It can be gleaned on the table the significant relationship between teachers' performance in terms of social presence along with organizational commitment (.225), professional commitment (.789) and job involvement (.112) were highly significant at .01 level while organizational citizenship (.088) was significant at .05 level.

In terms of cognitive presence along organizational commitment (.394), professional commitment (.851), organizational citizenship (.175) were highly significant at .01 level while job involvement (.088) was significant at .05 level.

Lastly, the teaching presence along with organizational commitment (.426), professional commitment (.847), organizational citizenship (.193) and job involvement (.120) were highly significant at .01 level. 
Table 20. Test of significant prediction of school heads' management practices on teacher's organizational behavior

\begin{tabular}{|c|c|c|c|c|c|c|}
\hline \multirow[b]{2}{*}{ Model } & \multirow[b]{2}{*}{ Predictors } & \multicolumn{2}{|c|}{$\begin{array}{l}\text { Unstandardized } \\
\text { Coefficients }\end{array}$} & \multirow{2}{*}{$\begin{array}{c}\begin{array}{c}\text { Standardized } \\
\text { Coefficients }\end{array} \\
\text { Beta }\end{array}$} & \multirow[t]{2}{*}{$\mathrm{t}$} & \multirow{2}{*}{ Sig. } \\
\hline & & B & Std. Error & & & \\
\hline \multirow{5}{*}{1} & (Constant) & $\begin{array}{c}3.97 \\
4\end{array}$ & 0.056 & & 70.900 & 0.000 \\
\hline & Designing Vision & $\begin{array}{c}0.04 \\
4\end{array}$ & 0.007 & 0.187 & 6.135 & 0.000 \\
\hline & Curriculum \& Instruction & $\begin{array}{c}0.03 \\
4\end{array}$ & 0.008 & 0.110 & 4.339 & 0.000 \\
\hline & $\begin{array}{l}\text { Protecting Instructional } \\
\text { Climate }\end{array}$ & $\begin{array}{c}0.01 \\
5\end{array}$ & 0.006 & 0.068 & 2.696 & 0.007 \\
\hline & Supervising Teachers & $\begin{array}{c}0.01 \\
8\end{array}$ & 0.008 & 0.070 & 2.281 & 0.023 \\
\hline
\end{tabular}

$\operatorname{Adj} R^{2}=4.1 \% ; F(4,1502)=16.980 ; p<0.01 ; N=1507$

Dependent Variable:

Organizational Behavior

A stepwise multiple linear regression was conducted with organizational behavior as the dependent variable and the five constructs of school head's management practices as independent variables. The multiple regression analysis revealed that Designing Vision, Curriculum and Instruction, Protecting Instructional Climate, and Supervising Teachers contributed significantly to the regression model $\mathrm{F}$ $(4,1502)=16.980, p<.01$ and accounted for $4.4 \%$ of the variation in organizational behavior scores which yields the final regression equation:

$$
\begin{aligned}
& \text { where } \\
& \text { OB }=\text { Organizational Behavior score; } \\
& C I=\text { Currigning Vision; } \\
& \\
& \text { PIC }=\text { Protecting Instructional Climate } \\
& S T=\text { Supervising Teachers }
\end{aligned}
$$

The equation above further indicates that for every 1- unit increase in organizational behavior score, there is a corresponding .044 unit increase in designing vision, holding other factors constant. Moreover, for every 1- unit increase in organizational behavior, there is a corresponding .034 unit increase in curriculum and instruction, maintaining other factors fixed. Also, for every 1-unit increase in organizational behavior score, there is a corresponding .015 units increase in protecting instructional climate keeping other factors constant. Finally, for every 1-unit increase in

\begin{tabular}{|c|c|c|c|c|c|c|}
\hline \multirow[b]{2}{*}{ Model } & \multirow[b]{2}{*}{ Predictors } & \multicolumn{2}{|c|}{$\begin{array}{l}\text { Unstandardized } \\
\text { Coefficients }\end{array}$} & \multirow{2}{*}{$\begin{array}{c}\begin{array}{c}\text { Standardized } \\
\text { Coefficients }\end{array} \\
\text { Beta } \\
\end{array}$} & \multirow{2}{*}{$\mathrm{t}$} & \multirow{2}{*}{ Sig. } \\
\hline & & B & Std. Error & & & \\
\hline \multirow{2}{*}{1} & (Constant) & $\begin{array}{c}0.15 \\
9\end{array}$ & 0.086 & & 1.846 & 0.065 \\
\hline & Professional Commitment & $\begin{array}{c}0.88 \\
6\end{array}$ & 0.015 & 0.824 & 59.028 & 0.000 \\
\hline
\end{tabular}
organizational behavior score, there is a corresponding .018 units increase in supervising teachers keeping other factors constant.

Table 21. Test of significant prediction of teacher's organizational behavior on their teaching performance 


\begin{tabular}{|c|c|c|c|c|c|}
\hline Organizational Commitment & $\begin{array}{c}0.02 \\
9\end{array}$ & 0.005 & 0.075 & 5.297 & 0.000 \\
\hline Organizational Citizenship & $\begin{array}{c}0.03 \\
5\end{array}$ & 0.010 & 0.047 & 3.468 & 0.001 \\
\hline Job Involvement & $\begin{array}{c}0.02 \\
1\end{array}$ & 0.008 & 0.033 & 2.473 & 0.014 \\
\hline
\end{tabular}

$\operatorname{Adj} R^{2}=74.6 \% ; F(4,1502)=1106.537 ; p<0.01 ; N=1507$

Dependent Variable:

Teacher's Performance

A stepwise multiple linear regression was conducted with teacher's performance as the dependent variable and the four constructs of teacher's organizational behavior as independent variables. The multiple regression analysis revealed that all of the four constructs of organizational behavior, namely professional commitment, organizational commitment, organizational citizenship, and job involvement, contributed significantly to the regression model $F(4,1502)=1106.537, p<.01$ and accounted for $74.6 \%$ of the variation in teacher's performance scores which yields the final regression equation:

where

$$
\begin{aligned}
& T P=.159+.886 P C+.0290 \text { Com }+.0350 \text { Cit }+.021 J I \\
& T P=\text { Teacher's Performance score; } \\
& P C=\text { Professional Commitment; } \\
& \text { OCom = Organizational Commitment; } \\
& \text { OCit = Organizational Citizenship; } \\
& \text { JI = Job Involvement }
\end{aligned}
$$

The equation above further indicates that for every 1- unit increase in teacher performance score, there is a corresponding .886 unit increase in professional commitment holding other factors constant. Moreover, for every 1- unit increase in teacher performance score, there is a corresponding .029 unit increase in organizational commitment maintaining other factors fixed. Also, for every 1unit increase in teacher performance score, there is a corresponding .035 units increase in

\begin{tabular}{|c|c|c|c|c|c|c|}
\hline \multirow[b]{2}{*}{ Model } & \multirow[b]{2}{*}{ Predictors } & \multicolumn{2}{|c|}{$\begin{array}{l}\text { Unstandardized } \\
\text { Coefficients }\end{array}$} & \multirow{2}{*}{$\begin{array}{c}\begin{array}{c}\text { Standardized } \\
\text { Coefficients }\end{array} \\
\text { Beta } \\
\end{array}$} & \multirow[t]{2}{*}{$\mathrm{t}$} & \multirow{2}{*}{ Sig. } \\
\hline & & B & Std. Error & & & \\
\hline \multirow{5}{*}{1} & (Constant) & $\begin{array}{c}1.23 \\
4\end{array}$ & 0.086 & & 14.302 & 0.000 \\
\hline & Monitoring Student Progress & $\begin{array}{c}0.73 \\
0\end{array}$ & 0.020 & 0.668 & 35.744 & 0.000 \\
\hline & $\begin{array}{l}\text { Protecting Instructional } \\
\text { Climate }\end{array}$ & $\begin{array}{c}0.10 \\
4\end{array}$ & 0.006 & 0.308 & 18.004 & 0.000 \\
\hline & Designing Vision & $\begin{array}{c}0.04 \\
6\end{array}$ & 0.006 & 0.128 & 7.646 & 0.000 \\
\hline & Curriculum and Instruction & $\begin{array}{c}0.03 \\
5\end{array}$ & 0.007 & 0.075 & 4.763 & 0.000 \\
\hline
\end{tabular}
organizational commitment keeping other factors constant. Finally, for every 1-unit increase in teacher performance score, there is a corresponding .021 units increase in job involvement keeping other factors constant.

Table 22. Test of significant prediction of school heads' management practices on teacher's performance

$\operatorname{Adj} R^{2}=64.4 \% ; F(4,1502)=683.280 ; p<0.01 ; N=1507$

Dependent Variable:

Teacher's Performance 
A stepwise multiple linear regression was conducted with teacher's performance as the dependent variable and the five constructs of school head's management practices as independent variables. The multiple regression analysis revealed that Monitoring Student Progress, Protecting Instructional Climate, Designing Vision, and Curriculum and Instruction contributed significantly to the regression model $\mathrm{F}(4,1502)=683.280, \mathrm{p}<.01$ and accounted for $64.4 \%$ of the variation in teacher's performance scores which yields the final regression equation:

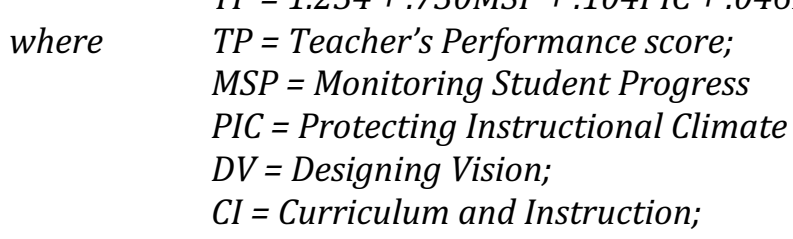

The equation above further indicates that for every 1- unit increase in teacher performance score, there is a corresponding .730 units increase in monitoring student progress holding other factors constant. Moreover, for every 1- unit increase in teacher performance score, there is a corresponding .104 units increase in protecting instructional climate, maintaining other factors fixed. Also, for every 1-unit increase in teacher performance score, there is a corresponding .046 units increase in designing vision keeping other factors constant. Finally, for every 1-unit increase in teacher performance score, there is a corresponding .015 units increase in curriculum and instruction, keeping other factors constant.

Table 23. Test of mediating effect of organizational behavior on the influence of school head's management practices on teacher's performance

\begin{tabular}{lcccrrr}
\hline \multicolumn{1}{c}{ Variable } & $B$ & $95 \%$ CI & SE $B$ & $\beta$ & $\mathrm{R}^{2}$ & $\Delta \mathrm{R}^{2}$ \\
\hline Step 1 & & & & & .181 & $.181^{* *}$ \\
(Constant) & 4.12 & {$[4.036,4.208]$} & .044 & & & \\
Management Practices & .168 & {$[.150, .186]$} & .009 & .425 & & \\
\hline Step 2 & 3.22 & & & & .200 & $.019^{* *}$ \\
$\quad$ Constant) & 6 & {$[2.923,3.529]$} & .155 & & \\
Management Practices & .161 & {$[.143, .179]$} & .009 & .407 & \\
$\quad$ Organizational Behavior & .214 & {$[.144, .283]$} & .035 & .140 & \\
\hline Step 1: $F(1,1505)=332.455 ; p<.01$ & & & Dependent & Variable:
\end{tabular}

Teacher Performance

Step 2: $F(2,1504)=188.326 ; p<.01$

Table 2 shows the two-stage hierarchical stepwise multiple regression results, which was conducted to determine the direct and indirect effects of management practices on teacher performance when the organizational behavior is used as the mediator variable. In step 1 , the $\mathrm{R}^{2}$ value of .181 revealed that the management practices explained $18.1 \%$ variance in the teacher performance with $F(1,1505)$ $=332.455, \mathrm{p}<.01$. In step 2 , the $\mathrm{R}^{2}$ value of .200 revealed that the school head's management practices and organizational behavior explained $20.0 \%$ variance in the teacher performance with $\mathrm{F}(2,1504)=$ $188.326, \mathrm{p}<.01$. The findings revealed that management practices $(\beta=.407)$ and organizational behavior $(\beta=.140)$ positively predicted teacher performance. The $\Delta \mathrm{R}^{2}$ value of .019 revealed $1.9 \%$ change in the variance of model 1 and model 2 and $\Delta \mathrm{F}(1,1504)=36.381, \mathrm{p}<.01$. The regression weights for management practices subsequently reduced from Model 1 to Model 2 (.425 to .407) but remained significant, which confirmed the partial mediation. More specifically, management practices have direct as well as indirect effects on teacher performance. 
The main point is that each school and the educational system ought to explain their own qualities and convictions proper to the setting inside which the schools work, and the expansive spotlight is on understudy learning and accomplishment (Harris, Day, Hadfield, Hopkins, Hargreaves, and Chapman, 2003). Obviously, expressed qualities and convictions become more huge in school improvement endeavors. Most school improvement programs urge administrators to foster clear scholastic objectives as the principal significant measure in the school improvement measure (Hallinger and Murphy, 2017).

\section{CONCLUSION}

Based on the results of the study, it was concluded that: (1). Most of the respondents were females and with 20-25 age bracket for teachers, bachelor's degree with 10 years below experience while the school heads belonged to 41-45 age bracket, MA Graduate with 16-20 years of experience; (2) The respondents demonstrated high extent on the management practices exhibited by the school heads in terms of designing vision, curriculum and instruction, supervising teachers, monitoring students' progress and protecting instructional climate; (3) The respondents exhibited commitment and involvement in terms of organizational behavior; (4) The teachers' performance along with the indicators were all very satisfactory; (5) There is a huge connection between the degrees of the executives practices and educators organizational behavior in terms of the following which resulted to the rejection of the hypothesis (a) Organizational Commitment along designing vision, monitoring students' progress and protecting instructional climate; (b) Professional Commitment along designing vision, curriculum and instruction, supervising teachers, monitoring students' progress and protecting instructional climate;(c) Organizational Citizenship along curriculum and instruction, supervising teachers, monitoring students' progress and protecting instructional climate; (d) Job Involvement along designing vision, monitoring students' progress and protecting instructional climate.; (6) There is a significant relationship between the levels of management practices and teachers' performance. Thus the result to the rejection of the hypothesis; (7) There is a significant relationship between the teachers' organizational behavior and teaching performance.

Thus the resulted to the rejection of the hypothesis; (8) The school heads' management practices significantly predicts the teachers organizational behavior. Thus the resulted to the rejection of the hypothesis; (9) The teachers' organizational behavior significantly predict their teaching performance. Thus, the resulted to the rejection of the hypothesis; (10) The management practices significantly predict the teacher's teaching performance. Thus, the result to the rejection of the hypothesis and (11) The management practices and organizational behavior positively predict the teaching performance of teachers. Thus, the resulted to the rejection of the hypothesis

\section{Limitation and Further Research}

This research was the initial stage of research on the development of strategic plan model that will be used to address the management practices of the school heads as well as to identify its impact to the teaching practices and performances in the five (5) city schools division of the Province of Laguna. Further research considering other variables not covered in the study is encouraged.

\section{REFERENCES}

Aquino, G. (2017). Administration and supervision for Philippine schools. The meaning and scope of school administration: Quezon City. Phoenix Press, Inc.

Ashkenas, R., Siegal, W., \& Spiegel, N. (2013). Mastering organizational complexity: A core competency for 21st century leaders. Research in Organizational Change and Development, 21, 2958.

Burke, W. (2014). Organization change: Theory and Practice. Los Angeles: Sage.

Brooks, J. S., \& Sutherland, I. E. (2014). Educational leadership in the Philippines: Principals‘ perspectives on problems and possibilities for change. Planning \& Changing, 45(3/4), 339- 355. 
Burke, W. (2014). Organization change: Theory and Practice. Los Angeles: Sage.

Calderon (2016) Multifactor Leadership Questionnaire: Manual and sampler set (3rd ed.). Menlo Park, CA: Mind Garden.

Denton (2016) Effective Human Relations: Personal and Organizational Applications. USA: Houghton Mifflin Company. Routledge

Ehrhart, M., Schneider, B., \& Macey, W. (2014). Organizational climate and culture. New York:

Hugghes (2018) Education. USA: Pacific Press Publishing Association. Fajardo, R. (2018). Effective leadership through parliamentary procedure: Theories of leadership. Quezon City: Rex Printing Company,Inc.

Frunză, S. (2017). Axiology, Leadership and Management Ethics. Meta: Research in Hermeneutics, Phenomenology, and Practical Philosophy, Vol. IX, No. 1: 284-299.

Gamage (2017). School based management theory research and practice. Colombo Karunaratnee and sons.

Harvey, J. (2013) The school principal as leader: guiding schools to better teaching and learning. The Wallace Foundation

Hallinger, P. (2013). Measurement properties of the principal instructional management rating scale technical report. New York: Springer

Hallinger, P. (2015) Assessing instructional leadership and with Principal instructional management rating scale,New York : Springer

Heaton, T. L. (2016). Handbook of instructional leadership. Retrieved from http://digitalcommons.cedarville.edu/education presentations/2 80.

Llagas A, Corpus B, \& Bilbao (2016). Becoming a 21 ${ }^{\text {st }}$ century educational leaders. Quezon City: Lorimar Publishng,Inc.

Lorenzo B. (2017) Distributed leadership according to the evidence. New York: Routledge.

Lunenburg \& Ornstein, 2014). Educational administration: Concepts and practices. Belmont, CA: Wadsworth Cengage Learning.

Martinez (2017). A social identity model of effectiveness in organizations research in organizational behavior, 25, 243-295.

Northouse P., (2014). Introduction to leadership concepts ad practice,2.

Northouse, P. (2013). Leadership: Theory and Practice. Thousand Oaks: SAGE

Nyagosia, O.P., Waweru,N.S. \& Njuguna, W.F. (2013). Factors influencing academic achievements in public schools in Central Kenya: An effective schools' perspective. Educational Research International, 2(2), 174-18. 
International Journal of Management, Entrepreneurship, Social Science and Humanities (IJMESH), Vol. 4 (2), 204-228 Management Practices of School Heads, Organizational Behavior, and Performance of Teachers in Distance 